\title{
PENINGKATAN HASIL BELAJAR PENDIDIKAN JASMANI OLAHRAGA DAN KESEHATAN PADA TEKNIK LARI MELALUI PEMBELAJARAN LANGSUNG SISWA KELAS X-2 SMA NEGERI 2 WATAMPONE KABUPATEN BONE
}

\author{
Mardiana \\ Guru SMA N 2 Watampone \\ mardiana@gmail.com
}

\begin{abstract}
ABSTRAK
Penelitian ini merupakan penelitian tindakan kelas bertujuan untuk mengetahui peningkatan hasil belajar Pendidikan Jasmani Olahraga dan Kesehatan pada Teknik Lari Melalui Pembelajaran Langsung Siswa Kelas X-2 SMA Negeri 2 Watampone Kabupaten Bone. Subjek penelitian ini adalah kelas X-2 SMA Negeri 2 Watampone Kabupaten Bone dengan jumlah siswa 34 orang. Pelaksanaan tindakan dilakukan dalam dua siklus, dan setiap siklus terdiri dari lima tahap, yaitu tahap refleksi awal, perencanaan tindakan, pelaksanaan tindakan, observasi, dan refleksi. Data yang terkumpul selanjutnya diolah dengan menggunakan analisis statistik deskriptif kuantitatif dan kualitatif. Hasil penelitian ini menyimpulkan bahwa; (1) Secara kuantitatif, hasil belajar Pendidikan Jasmani Olahraga dan Kesehatan pada teknik lari melalui pembelajaran langsung siswa Kelas X-2 SMA Negeri 2 Watampone Kabupaten Bone pada teknik lari sebelum pelaksanaan tindakan dikategorikan kurang. Setelah pelaksanaan tindakan siklus I dikategorikan sedang dengan nilai rata-rata 59,68 dan siklus II dikategorikan baik dengan nilai rata-rata 67,42, (2) Secara kualitatif persentase siswa kelas X-2 SMA Negeri 2 Watampone Kabupaten Bone terlibat secara aktif dalam proses belajar mengajar mengalami peningkatan pada teknik lari. Dari hasil analisis di atas, maka dapat disimpulkan bahwa dengan memberikan strategi pembelajaran langsung, dan memberikan umpan balik pada setiap tugas yang diberikan kepada siswa, dapat meningkatkan hasil belajar pendidikan Jasmani Olahraga Dan Kesehatan pada teknik lari melalui pembelajaran langsung siswa Kelas X-2 SMA Negeri 2 Watampone Kabupaten Bone baik secara kuantitatif maupun secara kualitatif.
\end{abstract}

Kata Kunci: Pendidikan Jasmani olahraga dan kesehatan, teknik lari, pembelajaran langsung

PENDAHULUAN

Pendidikan merupakn kebutuhan

pokok setiap manusia, sangat besar peranannya dalam menyukseskan pembangunan bangsa. Oleh karena itu, pemerintah beserta unsurunsur yang berkompeten di dalamnya harus benar-benar memperhatikan perkembangan serta kemajuan pendidikan di olahraga dan kesehatan. Pembangunan dapat berhasil mencapai sasaran yang ditargetkan jika manusia sebagai subjek sekaligus objek pembangunan memiliki iman dan taqwa serta menguasai ilmu pengetahuan dan teknologi (IPTEK).

Salah satu hal yang dapat menjadi fokus utama perhatian pemerintah pada saat ini adalah penyelenggaraan pendidikan formal yang diselenggarakan di sekolah mulai dari jenjang pendidikan dasar sampai jenjang pendidikan menengah atas. Di dalam pembukaan UUD 1945 dinyatakan bahwa tujuan kita membentuk Negara kesatuan RI ialah untuk mencerdaskan kehidupan bangsa.
Bangsa yang cerdas adalah bangsa yang dapat solusi dalam menghadapi berbagai kesulitan. Kenyataannya adalah dewasa ini bangsa Olahraga Dan Kesehatan dilanda dan masih berada ditengah-tengah krisis yang menyeluruh. Kita dilanda krisis politik, krisis ekonomi, krisis hukum, krisis kebudayaan dan tidak dapat disangkal juga di dalam bidang pendidikan.

Dalam model pengajaran langsung, guru memilih konteks pembelajaran yang tepat dengan cara mengaitkan pembelajaran dengan kehidupan nyata dan lingkungan dimana siswa hidup dan berbudaya. Jadi, penyajian pengetahuan, hasil belajar, keterampilan, nilai dan sikap yang ada dalam proses pembelajaran yang dilakukan, dan keterkaitan apa yang dipelajari di dalam kelas dengan kehidupan sehari-hari.

Dalam mengajar, pada umumnya kurang memperhatikan ketuntasan materi bagi setiap siswa. Namun berusaha agar tujuan instruksional dapat mencapai target, dan jarang 
memperhatikan target yang harus dicapai setiap siswa setelah pengajaran. Contoh kelemahan seperti inilah, yang menyebabkan rendahnya hasil belajar Penjas olahraga dan kesehatan siswa, tetapi ada pula guru yang mengajar dan hanya menekankan kepada siswa yang pandai saja, yang ditargetkan mencapai tujuan intruksional sedang siswa yang tidak begitu cerdas hanyalah sebagai tujuan intruksional yang diperoleh bahkan boleh jadi tidak memperoleh sama sekali.

Dua aspek penting dalam komponen guru yang turut mempengaruhi penguasaan siswa yang tergambar melalui hasil belajar yang diperoleh adalah : (i) kemampuan penguasaan materi pelajaran dan (ii) kemampuan memilih metode mengajar yang sesuai dengan materi yang akan disampaikan. Kombinasi kedua kemampuan ini sangat penting karena kadang kala guru sudah menguasai materi pelajaran dengan baik, akan tetapi salah atau kurang tepat dalam memilih metode mengajar. Pada akhirnya materi pelajaran yang disampaikan kurang dapat dipahami dengan baik oleh siswa.

Rendahnya nilai siswa pada mata pelajaran Pendidikan Jasmani Olahraga dan Kesehatan di jenjang pendidikan SMA pada hampir setiap pelaksanaan Ujian Akhir Nasional (UAN) merupakan indikasi bahwa tingkat penguasaan siswa terhadap mata pelajaran Pendidikan Jasmani Olahraga dan Kesehatan masih rendah. Secara sistematik, ini disebabkan oleh berbagai komponen, antara lain komponen siswa itu sendiri, komponen guru, dan komponen lingkungan.

Rata-rata hasil belajar Pendidikan Jasmani Olahraga dan Kesehatan pada teknik lari melalui pembelajaran langsung, siswa kelas X-2 SMA Negeri 2 Watampone Kabupaten Bone sebelum diadakan tindakan kelas hanya mencapai 51,35. Berdasarkan uraian di atas, penulis termotivasi untuk melakukan penelitian dengan judul peningkatan hasil belajar Penjas Olahraga Dan Kesehatan pada konsep lari melalui pengajaran langsung siswa kelas X-2 SMA Negeri 2 Watampone Kabupaten Bone.

\section{METODE PENELITIAN}

Penelitian ini adalah penelitian tindakan yang berbasis kelas (Class room Action Research) bertujuan untuk mengungkapkan hasil penelitian sesuai dengan fakta dan data yang diperoleh di lapangan. Subyek penelitian ini adalah siswa kelas X-2 SMA Negeri 2 Watampone Kabupaten Bone pada semester Genap tahun pelajaran 20122013 dengan jumlah siswa 34 orang. Pelaksanaan penelitian ini dilakukan pada bulan Januari-Juni 2013 yang di mulai minggu ke II Januari sampai minggu IV Juni 2013. Penelitian ini berlokasi di SMA Negeri 2 Watampone Kabupaten Bone yang beralamat di Jalan Jenderal Gatot Soebroto No. 1 Watampone Kabupaten Bone Provinsi Sulawesi Selatan. Yang menjadi sumber data dalam penelitian ini adalah guru dan siswa kelas X-2 SMA Negeri 2 Watampone Kabupaten Bone dan Jenis data berupa data kuantitatif dan kualitatif yang diperoleh melalui (1) observasi (2) catatan guru (3)tes hasil belajar.

Data yang diperoleh dari hasil pemberian tes, baik pada pelaksanaan tes awal maupun pada akhir pelaksanaan setiap siklus diolah dengan menggunakan statistik deskriptif. Teknik statistik untuk mendeskripsikan karakteristik siswa dan hasilnya disajikan dalam bentuk nilai tertinggi, nilai terendah, nilai rata-rata dan tabel distribusi frekuensi. Untuk memperoleh tanggapan yang jelas pada pembelajaran Pendidikan Jasmani Olahraga dan Kesehatan siswa kelas X-2 SMA Negeri 2 Watampone Kabupaten Bone, dituliskan dengan menggunakan lima kategori yang berpedoman pada sistem penilaian Depdiknas 2004 sebagi berikut:
Interval nilai

\begin{tabular}{ll}
\hline $81,0-100$ & Sangat tinggi \\
\hline $66,0-80,0$ & Tinggi \\
\hline $56,0-65,0$ & Sedang \\
\hline $41,0-55,0$ & Rendah \\
\hline $0-40,0$ & Sangat rendah \\
\hline
\end{tabular}

Dalam mengambil kesimpulan mengacu pada analisis statistik deskriptif. Hasil analisis yang diperoleh berupa data kuantitatif lalu di interpretasikan melalui teknik kategorisasi yang menjadi kualitas hasil pembelajaran. Kualitas hasil pembelajaran yang ditunjukkan berdasarkan teknik kategorisasi menjadi kesimpulan terhadap 
perlakuan tindakan yang di berikan kepada siswa. Pengambilan kesimpulan mengacu pada proses teknik analisis data, teknik kategorisasi dan interpretasi kualitas kategori.

\section{HASIL \& PEMBAHASAN}

Hasil belajar siswa kelas X-2 SMA Negeri 2 Watampone Kabupaten Bone sebelum pelaksanaan tindakan siklus 1, menunjukkan bahwa dari 34 siswa, nilai tertinggi diperoleh adalah 80 nilai terendah 40 dan nilai rata-rata 59,68. Dari keseluruhan nilai diperoleh siswa jika dikelompokkan dalam lima kategori, maka distribusi frekuensi dan kategori hasil belajar Pendidikan Jasmani Olahraga dan Kesehatan pada teknik lari siswa kelas X-2 SMA Negeri 2 Watampone Kabupaten Bone, yaitu; 0\% memiliki hasil belajar Pendidikan Jasmani Olahraga dan Kesehatan pada teknik lari dikategorikan sangat rendah, 29,41\% dikategorikan rendah, $38,24 \%$ di kategorikan sedang, $32,35 \%$ dikategorikan tinggi, dan $0 \%$ dikategorikan sangat tinggi.

Berdasarkan nilai hasil pemberian tes setelah pelaksanaan tindakan siklus I melalui pengajaran langsung terlihat bahwa secara umum hasil belajar Pendidikan Jasmani Olahraga dan Kesehatan pada teknik lari siswa kelas X-2 SMA Negeri 2 Watampone Kabupaten Bone di kategorikan sedang, hasil pengamatan menunjukkan bahwa masih rendah rata-rata perilaku siswa yang menunjukkan aktifitas mereka dalam melakukan proses belajar mengajar. Kemudian dari 34 siswa kelas X-2 SMA Negeri 2 Watampone Kabupaten Bone setelah pelaksanaan tindakan siklus II melalui pembelajaran langsung yang menjadi sampel penelitian ini, nilai tertinggi diperoleh adalah 85 , nilai terendah 45 dan nilai rata-rata 67,42. Dari keseluruhan nilai yang di peroleh siswa, jika dikelompokkan dalam lima kategori, maka distribusi frekuensi persentase dan kategori nilai hasil belajar Pendidikan Jasmani Olahraga dan Kesehatan pada teknik lari siswa kelas X-2 SMA Negeri 2 Watampone Kabupaten Bone setelah pelaksanaan tindakan melalui pembelajaran langsung menunjukkan bahwa dari 34 siswa semua kelas X-2 SMA Negeri 2 Watampone Kabupaten Bone yang menjadi sampel penelitian \% memilik hasil belajar Pendidikan Jasmani Olahraga dan Kesehatan pada teknik lari dikategorikan sangat rendah, 5,88\% dikategorikan rendah, $23,53 \%$ dikategorikan sedang, $61,77 \%$ dikategorikan tinggi, dan 8,82\% sangat tinggi. Dari nilai rata-rata siswa dikategorikan bahwa tingkat penguasaan teknik lari dalam Pendidikan Jasmani Olahraga dan Kesehatan siswa kelas X-2 SMA Negeri 2 Watampone Kabupaten Bone setelah menggunakan strategi pembelajaran langsung, yaitu; 2 orang $(5,88 \%)$ berada dalam tingkat penguasaan rendah, 8 orang $(23,53 \%)$ berada dalam tingkat penguasaan sedang, 21 orang $(61,77 \%)$ berada dalam tingkat penguasaan tinggi, dan 3 orang $(8,82 \%)$ berada dalam tingkat penguasaan sangat tinggi. Dengan demikian, dari nilai ratarata siswa setelah menggunakan strategi pembelajaran langsung dari siklus II terlihat bahwa tingkat penguasaan dan hasil belajar Pendidikan Jasmani Olahraga dan Kesehatan pada teknik lari melalui pembelajaran langsung, siswa kelas X-2 SMA Negeri 2 Watampone Kabupaten Bone adalah meningkat dari siklus I kategori cukup (C) meningkat menjadi kategori baik (B)..

\section{KESIMPULAN \& SARAN}

Dari hasil penelitian dapat disimpulkan sebagai berikut: (1)Secara kuantitatif hasil belajar Pendidikan Jasmani Olahraga dan Kesehatan pada teknik lari siswa kelas X-2 SMA Negeri 2 Watampone Kabupaten Bone setelah pelaksanaan tindakan siklus I melalui penerapan pembelajaran Langsung dikategorikan sedang dengan nilai rata-rata 59,68 dan setelah pelaksanaan siklus II dikategorikan baik dengan nilai rata-rata 67,42., (2) Secara kualitatif, persentase hasil belajar siswa kelas X-2 SMA Negeri 2 Watampone Kabupaten Bone yang terlibat secara aktif dalam pelaksanaan proses pembelajaran mengalami peningkatan pada teknik lari siswa kelas X-2 SMA Negeri 2 Watampone Kabupaten Bone. Begitu pula setelah pelaksanaan tindakan khususnya pada beberapa orang siswa yang pada pelaksanaan siklus I masih bermasalah khususnya pemahaman dan tingkah laku siswa pada siklus II dapat teratasi.

Berdasarkan pengamatan selama pelaksanaan dan hasil yang didapat dari penelitian tindakan kelas ini, peneliti menyampaikan saran sebagai berikut: (1) Kepada siswa, disarankan agar dapat mengerjakan tugas yang di berikan karena dapat mengaktifkan siswa di satu sisi serta menjadi informasi bagi guru tentang tingkat pemahaman siswa terhadap materi yang diberikan. (2) Kepada guru pelajaran Penjas 
Olahraga Dan Kesehatan, agar dalam setiap pelaksanaan strategi pembelajaran langsung hendaknya di terapkan dengan sebaik-baiknya sehingga dapat meningkatkan pemahaman dan hasil belajar serta aktifitas siswa. (3) Kepada peneliti selanjutnya kiranya dapat mengadakan penelitian lanjutan untuk memperkuat dan mengembangkan hasil penelitian.

\section{DAFTAR PUSTAKA}

Badan Standar Nasional Pendidikan. 2006. Standar isi. Jakarta: BNSP.

Dimayati dan Pudjiono. 1983. Belajar dan Pembelajaran. Jakarta: Rineka Cipta.

Endang. S. 2003. Pembelajaran Langsung. Direktorat Pendidikan Lanjutan Atas. Jakarta: Departemen Pendidikan Nasional.

Kardi, S. \& M. Nur. 2000. Pengajaran Langsung UNESA. Surabaya: University Press.

Mirsehell J. S. Nasution. 1995. Mengajar dengan Sukses. Jakarta: Bumi Aksara.

Nurcholis, Hanif \& Mafrukhi. 2007. Saya Senang Penjas Olahraga Dan Kesehatan untuk SMA Kelas X. Jakarta: Erlangga.

Sardiman. 2001. Interaksi dan Motivasi Belajar Mengajar. Jakarta: Rajawali Pers.

Slameto. 1955. Belajar dan Faktor-faktor yang Mempengaruhinya. Jakarta: Rineka Cipta.

Sudjana, Nana. 1992. Metode Statistik. Bandung: Tarsito.

Sudjana. Nana. 1992. Penilaian Hasil Proses Belajar Mengajar. Bandung: Sinar Bandung.

Tim Penyusun Kamus Pusat Pengembangan dan Pembinaan Penjas. 1994. Kamus Besar Penjas Olahraga Dan Kesehatan. Jakarta: Balai Pustaka.

Usman UM dan L Setiawati. 1993. Upaya Optimalisasi Kegiatan Belajar Mengajar. Bandung: PT. Remaja Rosdakarya. 